\title{
Enlightenment of Pragmatic Negative Transfer to College English Language Teaching
}

\author{
Qian Yang ${ }^{\mathrm{a}}$, Ting Xiao ${ }^{\mathrm{b}}$ \\ School of English, Chongqing Nanfang Translators College of SISU, Chongqing 401120, China \\ a9622741@qq.com, blilo822@126.com
}

Keywords: pragmatic negative transfer, pragmatic competence, English language teaching.

\begin{abstract}
In order to avoid pragmatic failures which are caused by different cultural values, social norms, thought patterns and communication styles and so on, it is useful not only to teach students' language aptitude, but also to give students more exposure to the target cultural environment. With analysis of different reasons and classifications of pragmatic negative transfer, this paper aims to produce some efficient ways to promote students' intercultural communication competence through English language teaching.
\end{abstract}

\section{Introduction}

Nowadays, intercultural communication is an inevitable trend. It is increasingly important and becomes one of the most prominent and significant activities in the $21^{\text {st }}$ century. For us, intercultural communication refers to communication among different cultures, which is the target of English language teaching. However, different cultures tend to be embedded with different communication situations in which participants may have different cultural background so that the process can be promoted with the initial thought patterns and cognition levels. And that is the manifestation of pragmatic negative transfer in English learning. More precisely, pragmatic negative transfer refers to a kind of pragmatic failure when native language pragmatic regulations have been highly applied in target language learning. To some extent, the native cultural perceptions and systems may be distinct enough to alter the intercultural communication event.

\section{Reasons for Pragmatic Negative Transfer}

As we all know that language is a kind of tool which focuses on the communication function. Furthermore, culture is the foundation of communication. When cultures differ, communication practices also differ. Samovar points out, "In modern society, different people communicate in different ways, as do people in different societies around the world; and the way people communicate is the way they live. It is their culture. Who says what to whom, when, where and how? These are questions of communication and culture. Communication and culture are inseparable." (Samovar, 1994). However, every culture has its unique value system, social convention and thought patterns and so on. Hence, there would be a lot of reasons for pragmatic negative transfer in intercultural communication.

Firstly, from the angle of the language learners, the unstable language aptitude cannot be ignored. The language learning aptitude refers to how an individual can learn a foreign language in a given amount of time and under given conditions. Moreover, it is the basis for applying language fluently and accurately. Without a good language aptitude, English learners would make some pragmatic mistakes in intercultural communication.

Secondly, pragmatic competence attaches great importance to language use, which can be considered as the most stringent part of making mistakes in intercultural communication. And it is mainly manifested in how to apply the language appropriately according to different contexts. However, learners who are quite affected by their native language would put some native expressions and ways into their English language learning process. They are not very sensitive in different cultural 
backgrounds and language usages. As a result, they would suffer a lot from poor pragmatic competence.

Thirdly, learners with little communication competence would pay little attention to the different cultural systems, such as different values and thought patterns, although it is essential in intercultural communication. Without a correct understanding of different cultures and the effects of negative transfer, learners will also make some pragmatic mistakes afterwards.

\section{Classifications of Pragmatic Negative Transfer}

According to Kasper's Pragmatics theory, pragmatic negative transfer can be divided into two types: pragmalinguistic negative transfer and sociopragmatic negative transfer. The former refers to reciprocal transfer of some vocabularies, sentence structures and verbal communication strategies, while the latter involves some inappropriate transfers of social customs, values, thoughts patterns and so forth. In pragmalinguistic negative transfer, learners would apply some sentence structure mechanically in target language. For example, Americans give "We must have lunch together next time." usually at the end of a conversation, which is simply a kind of polite expressions or formulas to say "Goodbye!" However, English learners will take this polite expression as an oral invitation. This is why pragmatic mistakes would often occur with mechanical use of the native language system. On the other hand, sociopragmatic negative transfer takes place when the speaker copies the native contextual factors to the target language. Because of poor understanding of different cultural backgrounds, learners will also have some difficulties in intercultural communication. For example, when saying "Na Li,Na Li", "Guo Jiang,Guo Jiang" andv"Can Kui, Can Kui" in Chinese compliments, Chinese learners will translate directly into "I feel ashamed." However, it is not a good expression of being polite and modest but just a mistake from sociopragmatic negative transfer of Chinese social etiquette.

\section{Enlightenment of Pragmatic Negative Transfer to English Language Teaching}

As is known to all, culture is a complex source of pragmatic negative transfer. In this regard, English teachers should give a profound analysis of pragmatic failures. And the constant learning of pragmatic negative transfer will provide strategic suggestions on English learning and intercultural communication. When using the target language, some English learners will apply the pragmatic rules of their mother tongues mechanically due to the influence of their native language and cultures. It is a kind of cultural interference. In order to overcome this problem in English language learning process, some effective ways should be used to promote, such as students' pragmatic competence in English teaching.

\subsection{To Help Students Build Cultural Empathy of Intercultural Communication.}

The target of English teaching is to train and bring up talents in intercultural communication. Hence, it is more important to develop both students' communication competence and language aptitude in class and after class. And it is also important to help them further understand the cultures and traditions in different English societies, so as to correctly master the communication contexts and accurately use the language. Cultural empathy, a more specific term, means that the participants consciously and willingly shifts from one's cultural frame of reference and puts themselves in another cultural pattern. There are many effective ways to help students build cultural empathy. The first step is cultural self-consciousness. Students can engage it when communicating with different people and their values and attitudes, their way of life, and so forth. The second step is to stop intercepting one's actions and thoughts from native cultures. The importance of cultural empathy to the English language teaching cannot be ignored, because it is the basis of intercultural communication. For intercultural communication to be successful, teachers should help students learn different cultures which are not part of our patterns. 


\subsection{To Enhance the Cultural Background Information in English Teaching.}

It is not possible to learn English without having an understanding of what it involves and of what cultural activities are relevant of developing proficiency. Frankly speaking, culture teaching accounts for a very small part in the whole English teaching process, because more attentions have been paid to language points and sentence structures commonly. However, with the rapid development of social linguistics and intercultural communication theories, it is not sufficient to just teach language use itself, because language should be also a good way to manifest the culture. As a result, English language teaching should focus more about the culture input. That is to say, we shall learn and catch up with other outstanding cultures. On the basis of understanding different cultures and norms, students can absorb and draw lessons from all human civilization in order to enrich the communication background. Therefore, teachers should combine different teaching models, focus on a wider range of text types and analyze discourse patterns to train learners to meet expectations of the particular context type, so as to recognize the differences and reduce the pragmatic negative transfer problems.

\subsection{To Improve the Cognitive Environment in English Language Teaching.}

For some highly conscientious students, they are more open to try new experiences and try doing things in different ways. In order to improve students' communication competence, teachers should select appropriate contents and design good learning activities in a coherent way based on task-oriented approach. On one hand, communication competence is not something innate with us. There should be necessary conditions that exist for our use. Luckmann pointed out three conditions: knowledge, motivation and skills. It is important to note that competent communication requires all these three which can be gained through education, experience and guided practice. Hence, students can follow established conventions in the organization of different communication contexts in terms of good cognition. First, students can find out the causes of pragmatic failures. Second, they can pay attention to different cultural backgrounds, social norms and other environments. Lastly, students can conduct many activities such as doing English report, delivering speech and role plays and so on, in order to make a solid foundation of cognition in communication. The mentioned above are efficient techniques to provide some real situations in intercultural communication practice.

\section{Summary}

In English learning, students subconsciously use the structure, semantics and the linguistic rules of their mother tongues and even the cultural perspectives to conduct their own behaviors in intercultural communication. When they make such kind of mistakes compared to the pragmatic failures, we can understand that because they are superficial. However, if students cannot use language context appropriately, intercultural communication cannot go very smoothly. That is why students' pragmatic competence and cognition should be strengthened in English language teaching. It is quite necessary to differentiate different cultural values, thoughts patterns, social norms and communication strategies. In this regard, this paper has provided strategic suggestions on English language teaching, so as to reduce the effects of pragmatic negative transfer and help students to understand other cultures and establish confidence in intercultural communication.

\section{References}

[1]. Deng Yanchang, et al. Language and Culture. Beijing: Foreign Language Teaching and Research Press, 1989, p. 56-58.

[2]. Jia Yuxin, et al. Intercultural Communication. Shanghai: Shanghai Foreign Language Education Press, 1997, p. 79.

[3]. Kasper G., et al. Interlanguage Pragmatics. Oxford: OUP, 1992, p. 101-102. 
[4]. Larry A. Samovar, et al. Communication between Cultures. California: Wadsworth Publishing Company, 1994, p. 44-45.

[5]. Leech, G., et al. Principles of Pragmatics. New York: Longman, 1986, p. 89-90.

[6]. Myron Luckmann, et al. Intercultural Competence: Interpersonal Communication across Cultures. Boston: Allyn and Bacon, 2003, p. 68-69.

[7]. Peterson Brooks, et al. Cultural Intelligence. London: Oxford University Press, 2000, p. 102-103.

[8]. Wang Hongyin, et al. Intercultural Communication: How to Communicate with Foreigners. Beijing: Foreign Language Teaching and Research Press, 1996, p. 55-58. 